\title{
Effect of Dementia, Family Support, Peer Support, Type of Residence, and Marital Status on Quality of Life of the Elderly in Surakarta, Central Java
}

\author{
Sri Suwarni'), RB. Soemanto²), Aris Sudiyanto3) \\ ${ }^{1)}$ School of Health Polytechnics, Ministry of Health, Surakarta \\ 2)Faculty of Social and Political Sciences, Universitas Sebelas Maret \\ 3)Department of Psychiatry, Faculty of Medicine, Universitas Sebelas Maret
}

\begin{abstract}
Background: The aging population is increasing in Indonesia and worldwide. Indonesia is one of the countries that has high aging population structure. As such, the quality of life of the elderly is of major concern. This study aimed to determine the effect of dementia, family support, peer support, type of residence, and marital status on quality of life of the elderly in Surakarta, Central Java.

Subjects and Method: This was an analytical observational study with cross-sectional design. A total sample of 218 elderly people in Surakarta, Central Java, was selected for this study by fixed exposure sampling, with 1:3 ratio consisting of 50 elderly people living in Dharma Bakti nursing home and 168 elderly people living with their families in the community. The dependent variable was health-related quality of life. The independent variables were dementia, family support, peer support, type of residence, and marital status. The data were collected by questionnaire and analyzed by path analysis.

Results: Better quality of life of the elderly was directly increased by strong peer support $(b=0.25$, $\mathrm{p}<0.001)$, strong family support $(\mathrm{b}=0.59, \mathrm{p}=0.002)$, mild dementia $(\mathrm{b}=1.79, \mathrm{p}<0.001)$, and being married $(b=12.73, p=0.039)$. Better quality of life was also increased indirectly by strong peer support $(b=0.67, p=0.012)$ and living with families $(b=22.93, p<0.001)$, through family support.

Conclusion: Better quality of life of the elderly is directly increased by strong peer support, strong family support, mild dementia, and being married. It is indirectly increase by strong peer support and living with families.
\end{abstract}

Keyword: quality of life, dementia, family support, peer support, elderly

\section{Correspondence:}

Sri Suwarni. School of Health Polytechnics, Ministry of Health, Surakarta.

Email: tanasfa@gmail.com

\section{BACKGROUND}

$\overline{\text { Globally, the elderly population is predicted }}$ to increase. The proportion of the world population aged 60 years and above is predicted to increase from $12 \%$ to $22 \%$ in 2015 to 2050 (WHO, 2015). In Indonesia, the population over the age of 60 reaches 21.4 million (BPS, 2015). According to the Ministry of Health RI in 2014, since 2000 the percentage of the elderly population of Indonesia has exceeded 7 percent, which means Indonesia belongs to the group of countries with advanced age structures. The increase in life expectancy exceeds the birth rate so that the elderly population is high.

An elderly population increase can pose problems in health, psychological, economic and social aspects (Info DATIN, 2016). The gradual changes in the elderly lead to a decline in function and relate to a variety of individual abilities. Although it is a normal process, it will cause dependence while performing daily activities in life. Problems in the elderly will affect the 
Journal of Epidemiologi and Public Health (2018), 3(1): 83-94

https://doi.org/10.26911/jepublichealth.2018.03.01.07

quality of life, such as changes in social roles, feelings of loneliness, and dementia.

Referring to the World Health Organization Quality of life (WHOQOL) quality of life is an individual perception of their position in life. Cultural systems and values of residence relate to their goals, expectations, standards, and problems (WHO, 1995). Quality of life is often associated with physical and psychological condition, independence, social interaction, and environment.

Social interaction is very influential in human life in this case elderly. The elderly tendency for lack of socialization, decreased immunity, should do the household chores alone even for family members, is a problem that elderly people face in living the rest of their age. The problems of the physical, psychological, and social aspects that occur in the elderly are interconnected, thus increasing dependence on others. Reduced social contact is associated with declining quality of life in older people (Sok and Choi, 2012). Under these conditions, social support for the elderly is necessary for its well-being (Meléndede-Moral et al., 2013).

High social support lowers the risk of mental disorders, illness, death, and improved quality of life (Karnell et al, 2007; Reblin and Uchino, 2008). Family support, peer support, living environment, is a form of social support needed by the elderly. Friends and family are supporting the meaning of life and a stronger purpose (Krause, 2007).

Quality of life is closely linked to the well-being of the elderly, namely the social and material, spiritual, and social order of life, which includes the sense of clarity, decency, and peace of mind. Every elderly person needs the fulfillment of spiritual, spiritual, and social needs, for self, family, and society, by upholding human rights and obligations (Law No. 13 of 1998). Elderly wellbeing can be correlated with the quality of life. Real indicators can be seen from physical, psychological, and social relationships.

The research question of this study was whether there are effects of dementia, family support, support of middle-aged friends, residence, and marital status on the quality of life of elderly people.

\section{SUBJECTS AND METHOD \\ 1. Study design}

This was an analytic observational study with cross sectional design. The study was conducted at Dharma Bakti nursing home and community health center in Pajang, Laweyan, Surakarta, Central Java, from October to December 2017.

\section{Population and sample}

The population of this study was elderly who lived in Pajang, Laweyan, Surakarta, Central Java. A sample of 218 elderly was selected for this study by fixed exposure sampling.

\section{Study variables}

The dependent variable was quality life of elderly. The independent variables were dementia, marital status, residence, family support, and peer support.

\section{Operational definition of variable}

The elderly was defined as someone aged from 60 years and above who lived in Parma Bakti Nur Dharma nursing home and participated in the elderly Posyandu in Pajang sub-districts, Surakarta.

Dementia was defined as a cognitive disorder that occurred in a person during a screening test with Mini Mental State Examination (MMSE). Family support was defined as the family attitude, action, support, attention, and acceptance of the elderly. Peer support was defined as the support of elderly friends whose age and maturity levels were similar. The residence 
was defined as a place of advanced age to live and carry on daily activities.

Marital status was defined as the marital status between a man and a woman as husband and wife to form a family.

Quality of life was defined as the subject's assessment of the physical, psychological, relationship or interactional conditions, and social environment.

\section{Study instrument}

Dementia was measured by modified MiniMental State Examination (MMSE). Quality of life was measured by WHOQOL-BREF. Family support and peer support were measured by a set of questionnaire.

Cronbach alpha of dementia, family support, and peer support were 0.96, 0.97, and 0.96 , respectively, indicating that the questionnaire was reliable.

\section{Data analysis}

The univariate analysis used to describe the distribution of study variables and sample Table 1. Sample characteristics (categorical data)

\begin{tabular}{cccc}
\hline & Variable & Frequency & Percent \\
\hline Age (year) & Elderly (60-74 years) & 154 & $70.6 \%$ \\
& Old (75-90 years) & 64 & $29.4 \%$ \\
Sex & Male & 36 & $16.5 \%$ \\
& Female & 182 & $83.5 \%$ \\
Religion & Moslem & 193 & $88.5 \%$ \\
& Christian & 24 & $11 \%$ \\
Education & Catholic & 1 & $0.5 \%$ \\
& No schooling & 71 & $32.6 \%$ \\
& Elementary school & 80 & $36.7 \%$ \\
& Junior high school & 30 & $13.8 \%$ \\
Employment & Senior high school & 31 & $14.2 \%$ \\
& Graduate & 6 & $2.8 \%$ \\
& Home maker & 74 & $33.9 \%$ \\
& Farmer & 23 & $10.6 \%$ \\
Marital status & Civil servant & $6 \%$ \\
& Private worker & 13 & $49.5 \%$ \\
Residence & Mnmarried & 158 & $72.5 \%$ \\
& Marriew/ widower & 60 & $27.5 \%$ \\
Health condition & Nursing home & 54 & $24.8 \%$ \\
& With family/ alone & 164 & $75.2 \%$ \\
& Very good & 7 & $3.2 \%$ \\
& Good & 105 & $48.2 \%$ \\
& Fair & 83 & $38.1 \%$ \\
Health problem & Poor & 23 & $10.6 \%$ \\
& Healthy & 93 & $42.7 \%$ \\
\hline & Unhealthy & 125 &
\end{tabular}

characteristics. The result of the univariate analysis for categorical data was described in frequency and percent. The univariate analysis for continuous data was described in frequency, mean, standard deviation, minimum, and maximum.

The bivariate analysis was used to provide crude estimates of the effect of dementia, marital status, residence, family support, and peer support, on the elderly quality life. The bivariate analysis involving continuous data used Pearson correlation.

The multivariate analysis used path analysis model to determine the direct and indirect associations between endogenous and exogenous variables. Path analysis coefficients were used to measure the magnitude of the effect of variables.

\section{RESULTS}

\section{Univariate analysis}


Journal of Epidemiologi and Public Health (2018), 3(1): 83-94

https://doi.org/10.26911/jepublichealth.2018.03.01.07

Table 2. Sample characteristics (continuous data)

\begin{tabular}{lccccc}
\hline \multicolumn{1}{c}{ Variable } & N & Minimum & Maximum & Mean & Standard Deviation \\
\hline Dementia & 218 & O & 24 & 21.31 & 5.51 \\
Family support & 218 & 19 & 76 & 58.40 & 14.91 \\
Peer support & 218 & 14 & 60 & 67.32 & 10.29 \\
Quality of life & 218 & 45 & 462 & 210.98 & 43.76 \\
\hline
\end{tabular}

2. Bivariate analysis

Bivariate relationship involving continuous data was indicated by Pearson correlation coefficient (Table 3). The quality of life of the elderly was positively correlated with

Table 3. Bivariate relationship involving continuous data between quality of life and other variables, measured by Pearson correlation coefficient

\begin{tabular}{lcc}
\hline \multicolumn{1}{c}{ Variable } & $\mathbf{r}$ & $\mathbf{p}$ \\
\hline Mild dementia & 0.27 & $<0.001$ \\
Strong family support & 0.29 & $<0.001$ \\
Strong peer support & 0.22 & 0.001 \\
Living with family & 0.21 & 0.002 \\
Living with husband/wife & 0.21 & 0.002 \\
\hline
\end{tabular}

Table 4. The result of bivariate analysis on the difference of mean quality of life by various independent variables

\begin{tabular}{|c|c|c|c|c|c|}
\hline No & Variable & $\mathbf{N}$ & Mean & $\begin{array}{l}\text { Standard } \\
\text { Deviation }\end{array}$ & $\mathbf{p}$ \\
\hline \multirow[t]{3}{*}{1} & Dementia & & & & \\
\hline & - Mild & 110 & 77.69 & 9.12 & 0.003 \\
\hline & - Severe & 108 & $74 \cdot 30$ & $7 \cdot 38$ & \\
\hline \multirow[t]{3}{*}{2} & Family support & & & & \\
\hline & - Weak & 106 & 73.45 & 8.53 & $<0.001$ \\
\hline & - Strong & 112 & 78.43 & 7.67 & \\
\hline \multirow[t]{3}{*}{3} & Peer support & & & & \\
\hline & - Weak & 98 & 75.07 & $7 \cdot 98$ & 0.136 \\
\hline & - Strong & 120 & 76.78 & 8.77 & \\
\hline \multirow[t]{4}{*}{4} & Residence & & & & \\
\hline & - Nursing home & 52 & 73.15 & 6.63 & 0.020 \\
\hline & - Alone & 23 & 76.96 & 8.45 & \\
\hline & - Living with family & 143 & 76.90 & 8.85 & \\
\hline \multirow[t]{5}{*}{5} & Marital status & & & & \\
\hline & - Unmarried & 10 & 74.40 & 7.03 & 0.044 \\
\hline & - Married & 60 & 78.43 & 9.11 & \\
\hline & - Widow & 122 & 75.48 & 8.20 & \\
\hline & - Widower & 26 & 73.50 & 7.62 & \\
\hline
\end{tabular}

Table 4 shows that mean quality of life is low if the elderly has severe dementia, weak family support, weak peer group mild dementia, strong family support, strong peer support, living with family, and living with husband/wife, and these correlations were statistically significant. 
Suwarni et al./ Effect of Dementia, Family Support, Peer Support

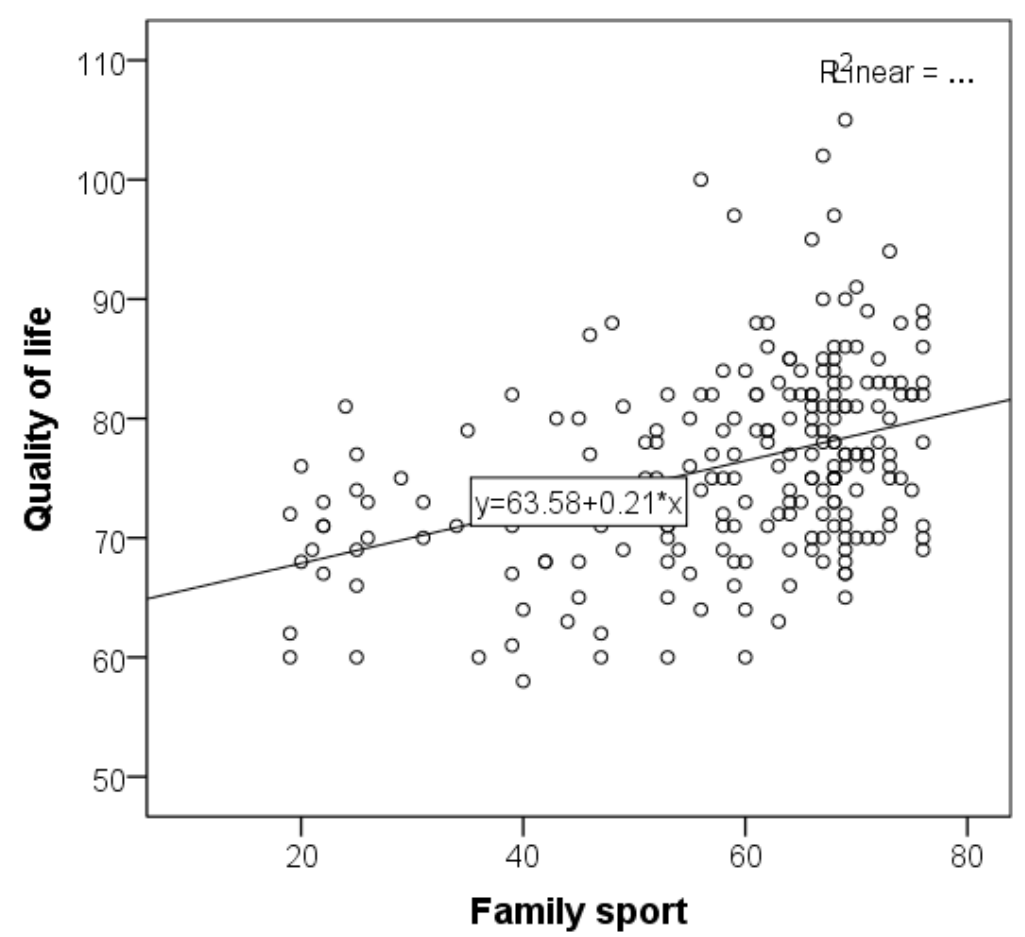

Figure 1. Positive weak correlation between family support and quality of life

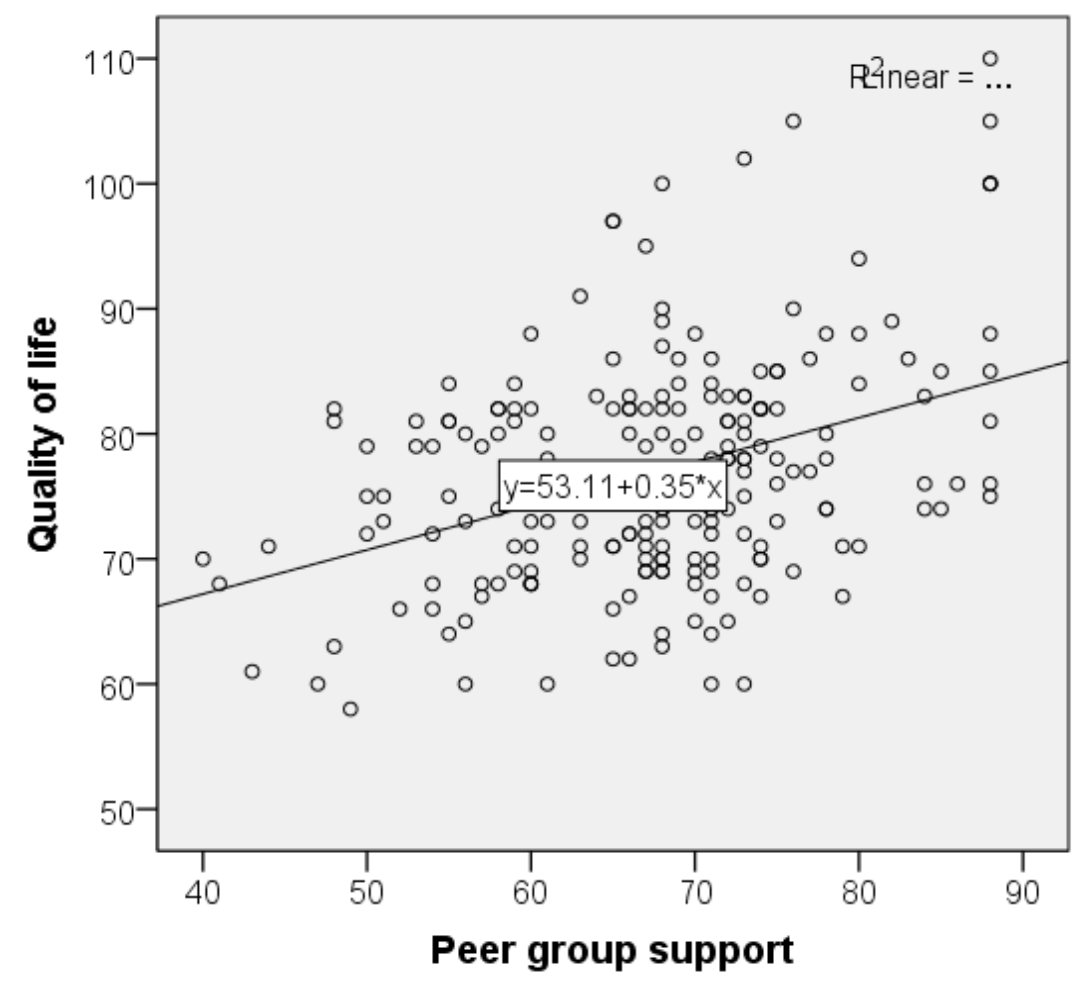

Figure 2. Weak positive correlation between peer group support and quality of life 
Journal of Epidemiologi and Public Health (2018), 3(1): 83-94

https://doi.org/10.26911/jepublichealth.2018.03.01.07

Figure 1 shows positive weak correlation between family support and quality of life. As expected the stronger family support, the better of quality of life. However, a bivariate analysis is only a suggestion on the direction of the relationship, since it is only a crude analysis that calls for further multivariate analysis to control for confounding factors.

Likewise, Figure 2 shows positive weak correlation between peer support and quality of life. As expected the stronger family support, the better of quality of life.

\section{Path analysis}

a. Model specification

b. Model specification illustrates the relationship between the variables under study. In the current model specification, there is a structural model with six measured variables (Figure 3).

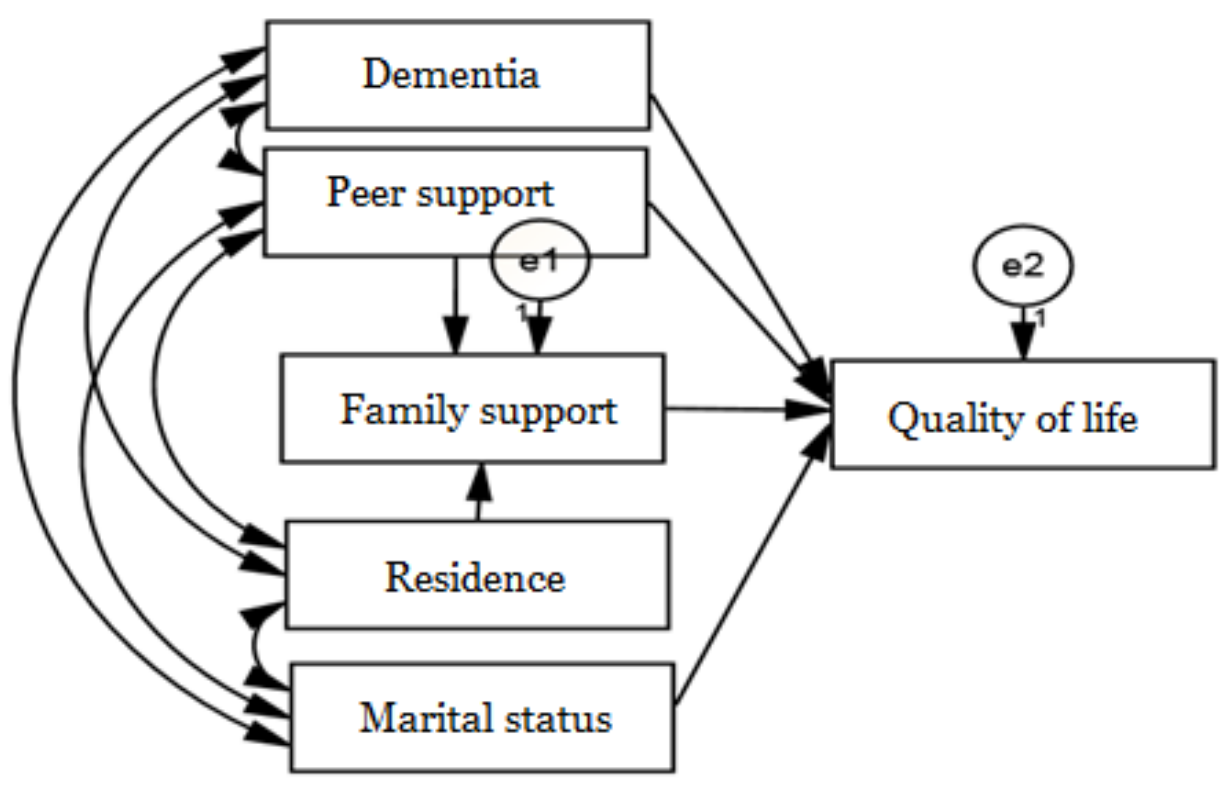

Figure 3. Structural model of path analysis without parameter estimates

\section{b. Model identification}

Path analysis can be done if it has a degree of freedom (df) $\geq 0$. The degree of freedom (df) calculation with the following formula: $\mathrm{df}=$ observed variable $\mathrm{x}$ (observed variable +1 ) / 2 - (endogenous variable+ exogenous variable + parameter).

Model identification on the quality of life of elderly determinants including:

1) Number of observed variable: 6

2) Endogenous variable: 2

3) Exogenous variable: 4

4) Parameter: 12

Degree of freedom value was 3 . c. Model fit

The goodness of fit between the structural model that has been made with the best variable relation model (saturated model) was checked. The results of checking the model goodness of fit are shown in Figure 2 and Table 4.

Figure 4 shows a structural model that has been estimated with SPSS AMOS 13 software. The parameter estimates were obtained according to the model. The goodness of fit of the path analysis model was indicated by CMIN $=0.32$, $\mathrm{p}$ value $=$ $0.957, \mathrm{GFI}=1.00>0.90, \mathrm{NFI}=1.00>0.90$, CFI $=1.00>0.90$, RMSEA $<0.001$. All of 
these indicators confirm that the specified model shows the goodness of fit, as such can be used to estimate the parameters.

\section{d. Parameter estimate}

Figure 3 shows the path analysis structural model without parameter estimates. Figure 4 shows the path analysis structural model with parameter estimates in the forms of the un-standardized path coefficients. The un-standardized path coefficient (b) shows the strength of the relationship between dependent and independent variables in the original measurement unit. Therefore, it cannot be used to compare the strength of the relationship between a dependent variable and a number of independent variable. In order to compare the strength of the relationship between a dependent variable and a number of independent variable, the standardized path coefficient can be used instead (see Table 5 the last column).

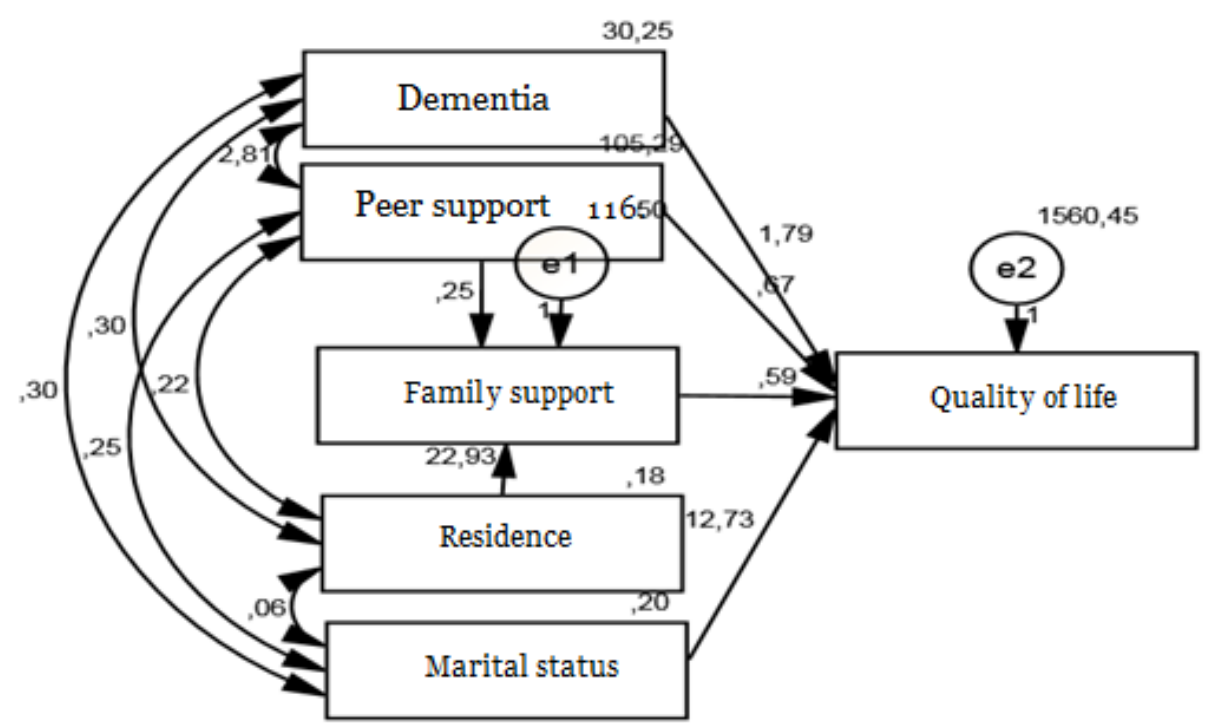

Figure 4. Structural model of path analysis with parameter estimates

Table 5. Path analysis on the effects of dementia, family support, peer support, residence, and marital status, on quality of life of the elderly

\begin{tabular}{llcccc}
\hline \multicolumn{1}{c}{ Independent variable } & Dependent variable & $\mathbf{b}^{*}$ & SE & p & B $^{* *}$ \\
\hline Direct effect & & & & & \\
Good quality of life & Mild dementia & 1.79 & 0.49 & $<0.001$ & 0.23 \\
Good quality of life & Strong family support & 0.59 & 0.19 & 0.002 & 0.20 \\
Good quality of life & Strong peer support & 0.67 & 0.27 & 0.012 & 0.16 \\
Good quality of life & Married & 12.73 & 6.17 & 0.039 & 0.13 \\
Indirect effect & & & & & \\
Strong family support & Strong peer support & 0.25 & 0.07 & $<0.001$ & 0.18 \\
Strong family support & Living with family & 22.93 & 1.72 & $<0.001$ & 0.66 \\
N $=218$ & & & & & \\
Fit Model & & & & & \\
CMIN=0.32 & p= 0.957 & & & & \\
GFI=1.00 & NFI 1.00 & & & & \\
CFI=1.00 & RMSEA $<0.001$ & & & & \\
$\mathrm{~b}^{*}=$ Unstandardized path analysis coeficient & & & & \\
$\mathrm{B}^{* *}=$ Standardized path analysis coeficient & & & \\
\hline
\end{tabular}


Journal of Epidemiologi and Public Health (2018), 3(1): 83-94

https://doi.org/10.26911/jepublichealth.2018.03.01.07

As Table 5 shows, mild dementia $(b=$ 1.79, $\mathrm{SE}=0.49, \mathrm{p}<0.001)$, married $(\mathrm{b}=$ 12.73, $\mathrm{SE}=6.17, \mathrm{p}=0.039$ ), strong family support $(\mathrm{b}=0.59, \mathrm{SE}=0.19, \mathrm{p}=0.002)$, strong peer support $(\mathrm{b}=0.67, \mathrm{SE}=0.27, \mathrm{p}=$ o.012) directly improved quality life of elderly. Quality life of elderly was indirectly affected by living with family member.

\section{DISCUSSION}

\section{The effect of dementia on the quality of life of the elderly}

Decreased cognitive function in the elderly is the cause of inability to perform normal daily activities that require the help of others. The main factors affecting the quality of life for people with dementia is the decrease in daily life activities (Koek, 2016). According to Clare et al. (2014), positive atmosphere such as feeling happy and life satisfaction are usually associated with higher quality of life in elderly with dementia. It is recommended to increase support for elderly with dementia to improve quality of life (Nikmat et al, 2015).

The results of path analysis in this study showed the effect of mild dementia variable compared with severe dementia on improving the quality of life of elderly people. Mild dementia effects on high quality of life. In contrast, severe dementia effects on low quality of life in elderly.

This result is in line with Haris et al. (2014) which states that dementia and depression affect the quality of life. Active participation in social activities and interactions with others can help to stimulate cognitive function and slow the occurrence of dementia in the elderly. Social activity and social attachment have been shown to have an effect on cognitive function in the elderly (Haris et al, 2014).

\section{The effect of family support on the quality of life of the elderly}

A family that interacts and is interdependent with one another gets emotional, instrumental, informational, rewarding support. Humans as social beings will be involved in a relationship and dependence. This is a form of support for each other. The support that occurs can be either positive or negative. Positive support will motivate in a good direction, but negative support will have a bad effect.

Positive family support affects the daily activity, physical condition, and mental state. People will be more enthusiastic about work and move to achieve the personal goal, so that the results will also be maximized. However, negative family support will cause stress, discomfort, laziness, and reluctance to behave, so that the results are not maximal or fail. This sometimes causes stress and despair.

The result of path analysis from the current study indicated that there was a direct effect of strong family support on the improvement of the quality of life. Family serves as a place to share with its members to meet the physical and emotional needs of each individual. Adaptation, partnership, maturity, affection, and togetherness, occur in the family life. Family support is needed during the life of elderly, so that they feel valued and cared for.

The elderly living with family gets all the four components of family support with varying depths. The elderly living in the nursing home have very limited support from the family, so the quality of life of elderly living in the nursing home tends to be low. The major cause of low family support is poor family economic conditions.

Family support is needed for the elderly throughout his lifetime. The role of family members in caring for the elderly is very important, by providing affection, 
interacting and communicating, helping to solve problems, and providing support to maximize life satisfaction. Life satisfaction arises from a feeling of calm and comfort. The result of this study is in line with the study by Meidikayanti and Wahyuni (2017) who reported an association between family support and quality of life in patients with type 2 diabetes mellitus.

\section{The effect of peer support on the quality of life of the elderly}

The result of path analysis in this study indicated that strong peer support directly or indirectly influenced the improvement of the quality of life of the elderly. Direct strong peer support improves the psychological aspect of the quality of life by reducing loneliness and the risk of depression. Strong peer support also affects increased family support.

Peer support motivates the elderly to keep the spirit of continuing life. Friendship provides the beneficial effects of mutual activities and pleasant interactions.

Increased age will cause a decrease in physical ability. This will limit the ability of a person to perform activities of daily living so that the quality of life of the elderly declined. The result of this study is in line with the study by Sreedevi et al. (2017) who reported that peer support increased the social domain of the quality of life of women with diabetes.

\section{Effect of residence on the quality of life of elderly people}

This study found that residence indirectly affects the quality of life of old age. Residence affects family support and family support affects the quality of life. So dwelling affects the quality of life of elderly subjects through family support.

The environment in the orphanage is different from that of the community. The elderly living in the home must adapt positively or negatively to the exposure of the environment and new friends (Nuryanti, 2012). This condition affects the health status of elderly (Wulandari, 2011).

The results of this study are in line with the results of research Putri et al. (2014) that compares the quality of life of elderly people living in families and homes.

\section{Effect of marital status on the quality of life of elderly people}

The study found that the marital status of the subject affects the quality of life. Subjects with marital status have a better quality of life than those who do not marry, widow or widower. In the elderly everyday spend more time in the house, so that the existence of a life partner will be very meaningful in the life and mind.

This study concludes that the status of dementia, family support, peer support, shelter, and marital status, affect the quality of life of the elderly.

\section{ACKNOWLEDGEMENT}

The author would like to extend gratitude to Municipality Office of Social Affairs for facilitating the access of the nursing home.

\begin{tabular}{c}
\hline REFERENCE \\
\hline BPS (2015). Statistik penduduk lanjut usia. \\
https://www.bappenas.go.id/files/- \\
data/Sumber_Daya_Manusia_dan_- \\
Kebudayaan/Statistik\%2oPenduduk\% \\
20Lanjut\%20Usia\%20Indonesia\%20 \\
2014.pdf. Diakses 13 Februari 2017. \\
Clare L, Woods RT, Nelis SM, Martyr A, \\
Markova IS, Roth I, Whitaker C J, \\
Morris RG (2014). Trajectories of \\
quality of life in early-stage dementia: \\
individual variations and predictors of \\
change. International Journal of Geri- \\
atric Psychiatry, 29(6):616-623. \\
Haris ER, Steven R, Handajani YS (2014). \\
Quality of life in elderly with cognitive \\
impairment and mental disorders: \\
cross sectional study in kelurahan
\end{tabular}


Journal of Epidemiologi and Public Health (2018), 3(1): 83-94

https://doi.org/10.26911/jepublichealth.2018.03.01.07

kalianyar, West Jakarta. Damianus Journal of Medicine.13(2): 117-127.

InfoDATIN: Pusat data dan informasi kementerian kesehatan RI; Situasi lanjut usia (Lanjut usia) di Indonesia 29 Mei 2016 - Hari lanjut usia nasional; diakses tanggal 3 Maret 2017

Karnell L, Christensen A, Rosenthal E, Magnuson J, Funk G (2007). Influence of social support on healthrelated quality of life outcomes in head and neck cancer: Head Neck. 29(2):143-6.

Koek MERHL (2016). Predictors of functional disability in mild cognitive impairment and dementia. Journal maturitas. MAT 6615.

Krause N (2007). Longitudinal study of social support and meaning in life. Psychology and Aging. 22(3): 456-69.

Meidikayanti W, Wahyuni CU (2017). Hubungan dukungan keluarga dengan kualitas hidup DM tipe 2 di puskesmas Pademawu. JBE; 5(2).

Manurung RPR (2014). Analisis Jalur (Path Analisis); Teori dan Aplikasi Dalam Riset Bisnis; Rineka Cipta Jakarta.

Melendez-Moral JC, Charco-Ruiz L, Mayordomo-Rodriguwz, Sales-Galan A (2013). Effects of a reminiscenceprogram among institutionalized elderly adults. Psicothema. 25(3): 319-23. Nikmat A, Hawthorne G, Al-Mashoor $S$ (2015). The comparison of quality of life among people with mild dementia in nursing home and home care, a preliminary report. Dementia: The international journal of social research and practice. 14(1): 114-125.

Nuryanti T (2012). Hubungan perubahan peran diri dengan tingkat depresi pada lanjut usia yang tinggal di UPT PSLU Pasuruan, Babat Lamongan.
Available :http://journal.unair.ac.id/fTitikN.pdf. diakses 22 November 2017.

Putri ST, Fitriana LA, Ningrum A, Sulastri A(2014). Studi komparatif: kualitas hidup lanjut usia yang tinggal bersama keluarga dan panti. http://download.portalgaruda.org/article.php?. diakses tanggal 5 Desember 2017.

Reblin M, Uchino B (2008). Social and emotional support and its implication for health. Curr opin psychiatry. 21(2): 201-5.

Sok S, Choi J (2012). Factors associated quality of life of elderly in non-paid or paid assisted living facilities. Korean $\mathrm{J}$ Adult Nurs. 24(2):99-108.

Sreedevi A, Unnikrishnan AG, Karimassery SR, Deepak KS (2017). The effect of yoga and peer support intervention on the quality of life of women with diabetes: Results of A randomized controlled trial. IJEM. 21(4):524-530.

Sujarweni (2012). SPSS Untuk Paramedis. Gava Medika Yogyakarta.

Undang-undang kesejahteraan lanjut usia No.13 tahun 1998.

WHO(1995). The WHOQOL Group. The world health organization quality of life assessment (WHOQOL): Position paper from the world health organization. Social science and medicine. 41: 1403-1409.

WHO (2015). Thematic briefs for the first who ministerial conference on global action against dementia, 16-17. Geneva: http://www.who.int/mental_health/neurology/dementia/thematic_briefs_dementia/en/. Diakses 6 April 2017.

Wulandari ASF (2011). Kejadian dan tingkat depresi pada lanjut usia: studi perbandingan di panti wreda dan komunitas. KTI Fakultas kedokteran 
Suwarni et al./ Effect of Dementia, Family Support, Peer Support

Universitas Diponegoro Semarang. Available:http://eprints.undip.ac.id/
Ayu_Fitri.pdf.diakses 20 November2017. 